\title{
Balázs Szent-Iványi
}

\section{Aid Allocation of the Emerging Central and Eastern European Donors}

\begin{abstract}
The paper examines the main characteristics of the (re)emerging foreign aid policies of the Visegrád countries (the Czech Republic, Hungary, Poland, Slovakia), concentrating on the allocation of their aid resources. We adopt an econometric approach, similar to the ones used in the literature for analyzing the aid allocation of the OECD DAC donors. Using this approach, we examine the various factors that influence aid allocation of the Visegrád countries, using data for the years between 2001 and 2008. Our most important conclusion is that the amount of aid a partner county gets from the four emerging donors is not influenced by the level of poverty or the previous performance (measured by the level of economic growth or the quality of institutions) of the recipients. The main determining factor seems to be geographic proximity, as countries in the Western-Balkans and the Post-Soviet region receive much more aid from the Visegrád countries than other recipients. Historical ties (pre1989 development relations) and international obligations in the case of Afghanistan and Iraq are also found to be significant explanatory factors. This allocation is in line with the foreign political and economic interests of these new donors. While there are clear similarities between the four donors, the paper also identifies some individual country characteristics.
\end{abstract}

\section{Keywords}

Visegrád countries, foreign aid, aid allocation, emerging donors

\section{Author information}

Balázs Szent-Iványi Balázs

Faculty of Economics, Corvinus University of Budapest, Fővám tér 8, Budapest, H-1093

Hungary. Email: balazs.szentivanyi@uni-corvinus.hu 


\section{Aid Allocation of the Emerging Central and Eastern European Donors}

\section{Introduction}

In the past decade a number of Central and Eastern European countries have emerged as new donors of foreign aid. Although these countries already had certain forms of developmentrelated cooperation with Third World countries during the Cold War, the pre-1989 experiences are difficult to compare with their current, (re)emerging aid policies. There is a clear pressure, related mostly to membership in the Organization for Economic Cooperation and Development (OECD) and the European Union (EU), for these new donors to align themselves with the norms and principles of the international development aid regime. Many special characteristics are observable however in the Central and Eastern European donors which predict that they will behave differently than the members of the OECD's Development Assistance Committee (DAC), the 'club' of advanced donor countries. In part this may be related to the fact that their foreign aid policies are still in their infancy, but it is also undeniable that their motivations for giving aid are somewhat different than those of the Western donors. It is logical to assume that the consequences of these different motivations are identifiable in the quality and allocation of aid provided by the emerging donors.

In this paper we examine the determining factors behind the aid allocation of the Central and Eastern European donors, using simple regression methods. Our goal is to show that these donors take different factors into consideration when making decisions on how to allocate their aid resources than what the general trend is among the OECD DAC countries. More specifically, the hypothesis of our research is that the Central and Eastern European donors do not take into account the recipients' need for aid (measured by their per capita income levels), nor their previous performance (measured by their growth performance or institutional quality). There is a growing body of literature that argues that these factors related to recipient countries' needs and merits are increasingly important in explaining the aid allocation of the OECD DAC countries, although it cannot be denied that this group of countries is highly heterogeneous. We argue however, that due to the emergent character of their aid policies and their different motivations for giving aid, Central and Eastern European countries will take other factors into consideration when making their aid allocation decisions. Our results indicate that, among others, geographic proximity and earlier relations (dating back to the Communist era) are important factors in determining the amount of aid a recipient country receives from the Central and Eastern European donors. We find no evidence of need and 
merit based aid allocation among these countries. In other words, these countries do not base their aid allocation decisions on the level of income or the quality of policies and institutions in recipient countries, as is increasingly common among OECD DAC members.

In our paper, we concentrate on aid allocation and do not analyze the quality of aid provided by the Central and Eastern European donors, as the lack of data would seriously hinder any such attempts. We reduce the scope of the Central and Eastern European donors we examine to the four members of the Visegrád Group (V4), namely the Czech Republic, Hungary, Poland and Slovakia, as they have the most advanced and significant foreign aid policies in the region. As we will show, there are considerable similarities between these countries in terms of foreign aid motivations, but also some important differences, which have not been identified by earlier research. There is also a practical reason for the selection of these four countries: they are the only countries among the Central and Eastern European donors for which the OECD provides comparable time series data on aid allocation, which is a sine qua non for our quantitative analysis.

To our knowledge, the aid allocation decisions of the V4 countries have so far not been scrutinized in a cross-sectional quantitative manner in the literature. Our paper contributes to the existing literature by applying the methods used for analyzing aid allocation decisions and the underlying motivations of the OECD DAC members to V4 countries, leading to a better understanding of the way these countries make decisions concerning aid allocation, and how this is different from the more established donor countries. Our results confirm the earlier case study evidence, but also raise some interesting questions related to the differences between the aid practices of these countries.

The paper is structured as follows: Section 1 reviews the literature on the aid allocation of the OECD DAC donors, with a special focus on the methodology of the various studies and their results. Section 2 lists the main common characteristics of the aid policies of the four Visegrád countries. Section 3 introduces a few stylized facts concerning the aid allocation of these emerging donors, and section 4 contains the description and estimation of our regression models. Section 5 concludes the paper. Throughout the paper, the terms aid, foreign aid, and development assistance are used as synonyms, and they always refer to the OECD's statistical category of ODA (official development assistance).

\section{Aid allocation of the OECD DAC donors}


There are no single and unambiguous conclusions in the literature examining the determinants of aid allocation. One of the main reasons for this is that each donor country may have several motivations for giving foreign aid and it can be difficult to pinpoint any single driving force. But even if we could identify the main determining factors in the case of a single donor country, the diversity among donors would still make any generalization exceedingly difficult. A second reason for the mixed of results in the literature is related to the question of what time period the various authors analyze. It is quite clear that the aid allocation decisions of donors were influenced by different factors during the Cold War than the ones that are relevant today.

The main models for explaining aid allocation in the literature are the 'recipient need' and the 'donor interest' models (McKinley and Little 1979; Gounder 1994; McGillicray 2003). According to the former, aid allocation should be driven by the needs of the recipients, therefore countries with lower incomes, higher levels of poverty, or lower levels of human development should receive more aid. The donor interest model on the other hand states that foreign aid serves donor interests, and thus those countries will receive more resources which have some kind of political, economic or other relations with the given donors. Although this distinction is to some extent flawed, as donors may have interests in giving aid to poor countries to reduce poverty (i.e. poverty reduction can reflect both recipient need and donor interest), it has become a frequent point of reference in the literature.

The majority of authors analyzing the period of the Cold War clearly subscribe to the donor interest model. They conclude that aid allocation decisions were primarily driven by strategic and geopolitical considerations, and so donors usually gave more aid to countries that were important to them due to some strategic reason. Aid was used as a tool of influence in this context. Alesina and Dollar (2000) for example showed that during the Cold War the donors gave more aid to those recipients with which they had longer colonial ties or which belonged to the same alliance system as they did. The case of the United States is well known, which used aid to achieve geopolitical goals ever since the birth of foreign aid (Morgenthau 1963), as it gave more resources to those countries which were especially important in the containment of regional Soviet influence. Israel and Egypt, especially after the 1979 Camp David agreement, also received huge amounts of US assistance. McKinley and Little (1979: 243) came to the conclusion that there are "no grounds for asserting that humanitarian criteria have any significant direct influence" on aid US allocation. 
However, during the Cold War, economic and trade considerations also meant an important motivation for donors. In an influential early study, Maizels and Nissanke (1984) argued that among other motivations, donors give more aid to countries with which they have higher volumes of trade. There is a relative consensus in the literature that during the Cold War the previous performance of the recipients, the quality of their political leadership, the level of poverty (Maizels and Nissanke 1984), the respect of human rights (Neumayer 2003) or the level of corruption (Alesina and Weder 2002) were not decisive factors in determining the amount of aid they received from the donors. Cases like the relationship between the USA and Zaire (today's Democratic Republic of Congo) illustrate well that recipient merit was not an important factor (Weissmann 1997).

Although the literature examining the Post-Cold War era also has mixed conclusions, there seems to be some degree of consensus concerning the fact that changes have occurred in donor behavior and also in aid allocation. It is a well documented fact that aid levels have decreased during the 1990's, but a resurgence of aid can be observed after the turn of the Millennium. The content of foreign aid has also changed in the past two decades. According to Burnell (2005: 4), the end of the Cold War "provided an enabling environment for new political objectives and aid rationales, namely democracy, 'good governance' and human rights, to be sought directly via projects or programmes and also through adding political conditionalities [...]." Many new issues have also arisen, such as the integration of gender and civil society into foreign aid (Lister and Carbone 2006), post-conflict rehabilitation (Collier et al. 2003) or more recently climate change (World Bank 2009a).

The shifts in the content and scope of foreign aid make it reasonable to assume that aid allocation may also have changed. Dollar and Levine (2004) for example came to the conclusion that since the second half of the nineties an increasing number of donors are taking the previous performance (measured by the quality of institutions and policies using the World Bank's Country Policy and Institutional Assessment [CPIA] index) and levels of income of the recipients into consideration when deciding on how to allocate their aid. Their findings are supported by the conclusions of Isopi and Mavrotas (2006). Bandyopadhyay and Wall (2006), also examining the post-1989 period found that aid and per capita income have been negatively related, while aid has been positively related to infant mortality, human rights, and government effectiveness. 
The reason behind this perceived shift from donor interests to recipient needs may be related to increased ethical considerations of the donors, but probably security-related aspects are the most important. Perhaps it does not even mean a shift towards recipient needs, rather a shift within donor interests. ${ }^{1}$ According to Burnell (2005) the two main reasons behind the resurgence of aid and the changes in aid policies (and thus allocation) are globalization and the 9/11 terrorist attacks. The latter has dramatically shown that due to globalization, the indirect effects of global poverty, state weakness and frustrations over failed modernization in developing countries can increasingly affect rich countries as well. However, terrorism is not the only security threat that is (directly or indirectly) related to poverty. Mass migration and trafficking in human beings, the emergence and spread of new diseases, organized crime and violent conflict are all issues that require the attention of donors.

Many donor countries may have recognized that foreign aid can serve as a tool for battling such global threats by promoting economic growth, decreasing poverty and fostering democratization (Brainad et al 2003; Rotberg 2002). For aid to actually achieve these goals, it must be more effective and better allocated. As shown by Collier and Dollar (2002), there is a close link between the allocation of aid and its overall effectiveness. According to their results, the number of people pulled out of poverty can be maximized if those countries receive the most aid where per capita incomes are low, but policies and institutions are of good quality. McGillivray et al (2005), in a review on the empirical literature argued that aid effectiveness has been increasing since the 1990's, which may in part be due to a more effective allocation of aid.

Most of the works mentioned above seek to make generalizations on the level the entire foreign aid regime. Such an approach however may be misleading, as it masks the potential heterogeneity between donors. While one can agree that there seems to be a general trend among OECD DAC in moving towards a 'need and merit' based aid allocation model, this is hardly true for all individual donor countries. Therefore, many authors concentrate only on a single donor, or a group of donors, and try to establish the factors that effect their aid allocation decisions. This approach allows for more clear-cut conclusions, as it does not seek to generalize results for the heterogeneous group of all aid-giving countries (Gounder 1984; Schraeder, Hook and Taylor 1998; Berthélemy 2006). According to these studies, the well-

\footnotetext{
${ }^{1}$ Danielson and Wohlgemuth (2005) argue that donors such as Sweden are not driven by altruism, but rather a kind of "enlightened egoism". This refers to the fact that such countries have recognized that instead of short term economic and foreign policy benefits, it is in their long term national security interest to decrease global poverty.
} 
known, although simplistic cleavage between 'altruistic' and 'egoistic' OECD DAC donors is clearly identifiable. While many donors (such as Sweden, Norway, Denmark, Luxembourg, the Netherlands or the United Kingdom) do take into consideration the needs and merits of the recipients when determining the allocation of their aid; others, such as the United States, Japan, Italy or Greece seem more interested in furthering their own shorter term interests, and they try to reap the immediate economic benefits from foreign aid. Still, it is possible to identify some shift even in US foreign aid policy in the past decade, such as the creation of the Millennium Challenge Account in 2004 (Radelet 2003).

Most of the works cited above use regression methods to identify the main factors which influence the allocation of foreign aid. The dependent variable in such regressions is the amount of aid a recipient receives (either from one donor, or all donors). The independent variables represent such factors which may influence this amount, but of course taking all such factors into account is not possible. In fact, quantifying some of the determinants of aid allocation into variables in a regression model raises many questions. The main works in the literature usually use the following independent variables (Maizels and Nissanke 1984; Alesina and Dollar 2000; Berthélemy 2006; Younas 2008):

- variables indicating recipient need, such as gross domestic product (GDP) per capita, levels of poverty or some measure of human development;

- variables indicating the merits or previous performance of the recipient, which try to capture how much aid the recipient 'deserves', and how effectively it can use these resources. This can be measured by previous levels of economic growth, the quality of economic and political institutions, the quality of economic policies or the level of corruption;

- variables indicating donor interests, measuring the intensity of relations between the recipient and the donor(s), such as those indicating former colonial ties, the volume of bilateral trade, the stock of bilateral investments, the participation in a common military alliance, or even voting together in the UN General Assembly;

- other variables, such as the size of the population in the recipient country.

The models in the literature are usually estimated using panel data in order to increase the number of observations in the regression and control for recipient and donor fixed effects, following the methods suggested by Trumbull and Wall (1994). It must be noted however that the results of such regression-based studies must always be treated with a degree of skepticism. Due to the inherent uncertainties of the method, conclusions and policy 
recommendations based on regression analysis should only be accepted if they are also triangulated by other methods. However, regressions are still the most common method used for analyzing aid allocation decisions, and they can be extremely useful for testing broad hypothesis generated by case studies: we feel that this is exactly what is needed in the case of the V4 donors. So far, according to our knowledge, only descriptive case studies have been published to analyze the foreign aid policies of these countries. Regression analysis can also help identify common patterns for these emerging donors which may be different than those observable in case of the OECD DAC donors.

Before we introduce our regression approach, we feel it is important to draw up the main characteristics of the foreign aid policies of the Visegrád countries, as well as the factors that determine these.

\section{The main characteristics of the Visegrád donors}

After the turn of the Millennium, the Czech Republic, Hungary, Poland and Slovakia all started to create, or recreate their international development policies. All four countries possessed some degree of former international development experience, since before 1989 they all had development relations with Third World countries in one form or another. During the Cold War the countries of the Eastern Block did not have sovereign foreign policies, and thus their international development efforts were also subordinated to the political, military and other interests of the Soviet Union. This influence could be pinpointed in the allocation of their aid: the recipients were mostly developing countries with socialist or strongly leftist governments, not to mention the formal allies of the Soviet Block (Carbone 2004: 244). It is difficult to compare these pre-1989 foreign aid policies of the Visegrád countries to the classic project- and program oriented approach of the OECD DAC member states, as they mainly consisted of the delivery of in kind goods, technical cooperation, scholarships and tied aid credits (Szentes s.a.; Baginski 2002). ${ }^{2}$

\footnotetext{
${ }^{2}$ A detailed scientific analysis of these pre-1989 development policies is missing from the literature. We must not however underestimate the importance of these policies. Hungary for example in the 1970's spent an average 0,7 percent of its national income on various forms of foreign aid, which is an extremely high level, even though the methodologies for calculating both national incomes and aid levels in the Eastern Block at the time do not permit comparisons with Western donors and current aid levels (HUN-IDA 2004; Szent-Iványi - Tétényi 2008). The opinion of Michaux (2002: 19) therefore, who states that the Central and Eastern European countries do not have any development traditions is clearly wrong.
} 
With the end of the Cold War and the initiation of the transition process, Czechoslovakia, Hungary and Poland all suspended their foreign aid policies, which was an understandable decision given the severe recession that the economic transformation process caused. With the European Community's 'Poland and Hungary: Assistance for Restructuring their Economies' (PHARE) program these countries became recipients of foreign aid. Throughout the nineties, foreign aid was basically restricted to giving a limited amount of scholarships to developing country students, as well as membership fees and other ad hoc contributions to international organizations (such as the World Health Organization, the International Labor Organization or the United Nations Development Program). In the case of Hungary, an important form of aid was the resources granted to ethnic Hungarians living in the Ukraine, Romania and the former Yugoslavia. But all together the nineties were characterized by the steep decline of foreign aid polices.

By the end of the decade an increasing, although rather implicit international pressure appeared towards the four countries to take a larger share in aiding poorer countries. At first, this pressure stemmed from membership in the $\mathrm{OECD},{ }^{3}$ and later the $\mathrm{EU}$ was also prominent in pushing these countries to create new foreign aid policies. ${ }^{4}$ Still, the issue of international development cooperation was spectacularly neglected during the accession negotiations, which signified the low political priority that both sides attached to it (Lightfoot 2008; Harmer and Cotterrell 2005: 11). Besides international pressure, other factors might have also contributed to the creation of these policies after the Millennium. Drozd (2007: 6) for example remarks that in the case of Poland an important factor was to demonstrate that the country's transition to a full-fledged market economy has been completed. All four countries laid down the legal, institutional and financial foundations of their new international development policies between 2001 and 2003, the process of which was helped by a joint capacity building project carried out by the Canadian International Development Agency (CIDA) and the United Nations Development Program (UNDP). It is clear therefore that the international development policies of the Western countries served as role-models for the reemerging foreign aid policies of the four Visegrád countries.

\footnotetext{
${ }^{3}$ The Czech Republic became a member of the OECD in 1995, followed by Hungary and Poland in 1996, and Slovakia in 2000. This however did not mean automatic membership in the OECD DAC, where the four countries have only observer status to this day.

${ }^{4}$ In the case of the EU, this pressure mainly comes from softer acquis, such as Council statements and declarations. In 2002 the European Council reaffirmed that the ODA/GNI target of $0.7 \%$ must be reached by 2015, and set an intermediate goal of $0.39 \%$ by 2006 (European Council 2002: 6). In 2005, a new intermediate goal was established for 2010 of $0.56 \%$, and a separate goal was set for the new member states of $0.17 \%$ (Bucar and Mrak 2007: 7). Also, in 2005 a joint statement by the Commission, the Council and the Parliament, entitled the 'European Consensus on Development', created a new framework for the EU's common development policy and also laid done many requirements for the individual member states (European Consensus 2005).
} 
Taken this historical background into consideration, it is difficult to compare the current emerging foreign aid policies of the four countries with those of the OECD DAC donors, who have many decades of experience in providing foreign aid. These differing characteristics lead to different goals and motivations for the Visegrád countries than the ones observable in case of many Western donors. The main characteristics are the following:

- The Visegrád countries are relatively small (or in case of Poland medium-sized) states and neither of them were colonial powers, which leads to the conclusion that their former political relations with developing countries were sporadic at best. As they did not have sovereign foreign policies before the transition, they did not have the possibility to form relationships with developing countries according to their own national interests (Baginski 2002; Carbone 2004).

- As a partial consequence of the above, the Visegrád countries only have limited economic ties today with developing countries as well.

- It seems like many people in the Visegrád countries see themselves less affected by the security threats caused by global poverty and state weakness, as compared to the Western-European countries or the United States. While this may or may not be the case, one can probably argue that these perceptions may also have an effect on the international development policies of these countries.

- The questions of international development are usually not part of the public discourse agendas in the four countries, and so public awareness about these issues is also much lower than in the Western donors. Bucar and Mrak (2007: 11) argue that there is no significant constituency for development cooperation in these countries. This is well reflected by the various Eurobarometer surveys, which also show at the same time that the citizens of the Visegrád countries are not indifferent towards the situation in the developing countries from a moral standpoint (see for example Eurobarometer 2007).

- The four countries are facing severe development challenges of their own and so it may be difficult for governments to justify spending large amounts on foreign aid towards the taxpayers. Wishes to join the euro-zone and the straightjacket of the Maastricht-criteria also limit any possibilities these countries may have for a quick increase in funds spent on foreign aid, not to mention the current economic crisis.

It is clear that the few characteristics listed above will definitely have an effect on the quantity, quality and allocation of the foreign aid disbursed by the four Central and Eastern 
European countries. We only make a few remarks concerning quantity and quality, as our research is mainly confined to examining the allocation of their resources.

The amount of aid disbursed by the Visegrád countries is quite low compared to the OECD DAC average, both compared to the GNI's of the respective donors and especially in absolute terms. Table 1 shows the evolution in the past years of the ODA/GNI figures of the four countries and compares it to the DAC average. Although an increasing trend is visible to some extent, 2007 and 2008 showed stagnation, and in case of Hungary a rather spectacular decline compared to previous years. With the exception of Hungary, where the decline of the ODA/GNI ration also meant the decline of the absolute amount spent on foreign aid, stagnating ratios hide increasing absolute amounts (OECD 2007a: 33; 2008: 33) for the rest of the V4 countries.

\section{[INSERT TABLE 1 HERE]}

It is difficult to draw any clear conclusions concerning the quality of aid channeled by the four countries. Even though some descriptive and even normative studies have been published in the past years (see for example Kiss 2007; Drozd 2007; Bucar and Mrak 2007; OECD 2007b; Szent-Iványi - Tétényi 2008; Lightfoot 2010), the scarcity of comparable data renders any such attempt almost impossible. These few existing studies do permit a fair amount of critical remarks concerning aid quality, but it must be kept in mind that we are dealing with emerging foreign aid policies, still in the phase of learning. Still, the most important generalizable conclusions from these studies are the following:

- The institutional settings for aid delivery in the four countries are highly fragmented. Too many organizations and ministries are involved, there is a lack of strategic focus, the proliferation of partners and sectors and thus resources is clearly present (OECD 2007b: 14; World Bank 2007: 3; Kiss 2007: 8-9; 11; Zagranica Group 2007: 15).

- Their foreign aid policies are highly donor-driven, the recipients have little influence on planning and programming resources. Recipient 'ownership', which refers to whether the countries receiving aid are in charge of (or at least have a substantial role in) planning and implementing the development projects financed by aid, is difficult to identify in practice (OECD 2007b: 20; Zagranica 2007: 19).

- The evaluation of projects is not given ample emphasis, feedback and organizational learning are neglected (OECD 2007b: 21). 
It is clear that more research is required in order to gain broader insights into the qualitative aspects of foreign aid channeled by the Visegrád countries. From our perspective however, the quality of aid is secondary, the main question is who they give it to and why. Taking the historical background and other characteristics of the four countries described in this section into account, it is possible to gain better insights into these aid allocation decisions.

\section{A few stylized facts on the aid allocation of the Visegrád Countries}

Perhaps one of the most striking features of the aid allocation of the Visegrád countries is that they seem to concentrate most of their resources on partners in their neighborhood, mainly the Western Balkans and the Post-Soviet region. Although the stability of these two regions is important for all European countries, it is a paramount interest for Central and Eastern Europe (Dangerfield 2009), as they would be the ones most hardly hit by potential instability in the forms of increased migration, decreasing international trade and foreign investments and increasing levels of organized crime. Avoiding further conflict in the former Yugoslavia and promoting political stability and economic growth in the Commonwealth of Independent States (CIS) is one of the most important foreign policy interests of the Visegrád countries. Some numbers relating to their aid allocation illustrates it well how important these two regions are for the four emerging donors.

According to data from the OECD's StatExtracts online database, Hungary channeled more than 61 percent of its bilateral ODA in 2008 to relatively poor European countries, with Serbia and the Ukraine being among the top three partners. The same figure for Poland is $47 \%$, and Belarus and Ukraine were by far the two most important recipients. European countries are also important in case of the Czech Republic and Slovakia, although the figures for 2008 are distorted due to large scale aid to Afghanistan in case of the former, and debt relief to Liberia in case of the latter. Besides Afghanistan, Serbia and Bosnia were the second and third largest recipients of Czech ODA in 2008.

Taking a more broader view, the partner countries of the four emerging Visegrád donors may be divided into the following three groups (with some exceptions):

- countries belonging to the immediate neighborhood, or in other words to the Western Balkans or the CIS region. Although there are major annual fluctuations in the amount of V4 aid given to these partner countries, the relative importance of these two regions has not changed since 2001; 
- Iraq and Afghanistan form a separate group, giving aid to them is a result of international obligations as NATO members and their close ties to the United States; ${ }^{5}$

- the final group is composed of partner countries "inherited" from the Communist period. These are the countries with whom development partnerships have already existed before the transition, such as Yemen, Ethiopia, Vietnam, Mongolia, Cambodia, Angola, Mozambique or Laos. Formerly (or in some cases even today) these countries all had socialist-oriented political systems, or for some other reason they hoped to gain (development or military) assistance from the Soviet Block.

The question arises why do the Visegrád countries choose far-flung developing recipients today, why don't they concentrate all their aid resources on their neighboring countries (and perhaps on any international obligations)? Their security-related motivations for giving aid clearly dictate giving aid to potentially unstable countries in their proximity. Being present in far away developing countries also entails costs that may be prohibitively high for such emerging donors. Also, they have much more limited economic and political ties with these countries, as elaborated in Section 2. The reason for supporting such countries, in our opinion, is international pressure, since both the EU and the OECD expect (although perhaps they do not explicitly state it) that the emerging Central and Eastern European donors support less developed countries as well (Michaux 2002; Drozd 2007: 10). If they have to select such partner countries, it seems a logical decision for them to select ones with which they have previously (before the transition) had relations and thus may have some experience.

\section{Regression approach, data and results}

\subsection{Model and data}

The few facts mentioned above and the grouping of partner countries still does not prove that the four emerging donors systematically allocate their based on different criteria than most OECD DAC donors do. In order to pinpoint the factors that influence the aid allocation decisions of the Visegrád countries we employ a simply regression approach, in some aspects similar to the ones used for analyzing the aid allocation decisions of the DAC members in the literature (Maizels and Nissanke 1984; Schraeder, Hook and Taylor 1998; Alesina and Dollar 2000; Dollar and Levine 2004; Berthélemy 2006; Younas 2008). The models used of course must be adapted to the characteristics of the Visegrád countries and limits posed by the availability of data.

\footnotetext{
${ }^{5}$ Hungary and the Czech Republic even manage two provincial reconstruction teams in Afghanistan.
} 
The dependent variable of our regression is the amount of aid a recipient country gets from the Visegrád donors (i.e. the gross bilateral ODA received by the various recipients from the Czech Republic, Hungary, Poland and Slovakia summed up). We have data on this variable from the StratExtracts Online database of the OECD for the years between 2001 and 2008. The literature on aid allocation prefers to use four or five year averages for such data in order to eliminate potential biases caused by large annual fluctuations in aid to any single countries (which are relatively common). Therefore, we decided to split our data into two four year episodes, thus each recipient country will constitute two observations, one for the period between 2001 and 2004 and a second for the years between 2005 and 2008. We estimate this model using a simple pooled ordinary least squares (OLS) method. We also tried using a country-year approach and estimated it with the fixed effects method as suggested by Trumbull and Wall (1994) as a robustness check for the pooled OLS method. Although the data on bilateral ODA published by the OECD is not perfect, as it includes money that does not actually leave the donor country such as debt relief or the costs of housing refugees, but it is not possible to clean the data from these distorting factors. We discuss the potential biases and limitations that this may cause in section 4.3.

As independent variables of the model we try to include the factors which may determine how much aid a recipient country got from the V4 donors between 2001 and 2008. The variables used are the following:

- The size of the recipient country's population, measured as an average in case of both the 2001-2004 and the 2005-2008 periods. Ceteris paribus, larger countries should receive more aid from the Visegrád countries than smaller ones. Data are from the International Monetary Fund (IMF).

- GDP per capita of the recipient countries in purchasing power parity (PPP). Poorer countries should get higher amounts of foreign aid, but we hypothesize that this relationship does not exist in case of the Visegrád donors. It is widely discussed in the literature on aid that there is an endogenous relationship between aid and income levels (see Roodman 2007 for accessible discussion on the topic). This endogenity comes from the potential two-way causality between aid and income levels: income may determine how much aid donors give to a country, but aid also increases income levels. In order to control for this potential bias, we measure GDP per capita in the year before the beginning of each of the two periods, i.e. in 2000 and 2004, instead of using averages for the entire period. The logic behind this approach is that GDP per 
capita in the previous years may influence how much aid a country gets, but is definitely not influenced by the average annual amount of aid channeled in the following four years. Data on PPP GDP per capita are from the IMF.

- GDP growth in the recipient country, which may signal both need for aid and performance and 'merit'. Countries with low levels of economic growth may need more aid to accelerate growth, but on the other hand donors may be more willing to reward 'good performers' with larger amounts of aid. In case of the Visegrád countries, we hypothesize that the growth rate of the recipient's GDP will not have any affect on how much aid it receives. As with GDP per capita, the problem of endogenity arises here as well, so we use a similar approach as above and lag the growth variables. Data on growth are also from the IMF.

- Institutional quality of the recipient country. As outlined in Section 1, some donors increasingly concentrate their aid on countries with 'good institutions'. We use two measures of institutional quality: the well known index of Freedom House for measuring political institutions and civil liberties;' ${ }^{6}$ and the 'rule of law' index published by the World Bank in its World Governance Indicators initiative. ${ }^{7}$ We hypothesize that neither indicator will have any explanatory power in case of the aid allocation by the Visegrád countries.

- We decided to include dummy variables in our model for the various groups of recipient countries, i.e. the Western Balkans, the CIS-region, Iraq and Afghanistan, as well as the Communist-era (pre-1989) recipients. We hypothesize that these dummies will have significant explanatory power.

- Due to the nature of the pooled-OLS approach, there is also dummy included for the second (2005-2008) period. This allows us to test whether there has been a general scaling up of bilateral aid by the V4 donors in the period between 2005 and 2008, as a result, for example, of their accession to the EU.

\footnotetext{
${ }^{6}$ Freedom House publishes two index numbers in their annual report "Freedom in the World", one measuring political rights, the other measuring civil liberties. Both are rated on a scale of 1 to 7 , with 1 representing the highest and 7 the lowest level of freedom. In our analysis, we have taken the two indicators and averaged them across countries to get a single indicator measuring the quality of political institutions.

${ }^{7}$ In its World Governance Indicators initiative, the World Bank publishes six indices: voice and accountability; political stability and absence of violence; government effectiveness; regulatory quality; rule of law; control of corruption. The rule of law index measures "the extent to which agents have confidence in and abide by the rules of society, including the quality of contract enforcement and property rights, the police, and the courts, as well as the likelihood of crime and violence" (World Bank 2009b: 1). These factors are one of the main determinants of whether it is worth doing long term investments in an economy. Thus, the rule of law index is a reasonably good measure of the economic institutions which affect long term growth and the effectiveness of aid. 'Rule of law' is measured on scale of -2.5 to 2.5 , where lower scores mean lower quality institutions.
} 
ODA and GDP data are measured in constant 2008 prices and exchange rates. It is regretful that there is no appropriate variable for measuring economic relations between the Visegrád donors and their aid receiving partners. In the literature on the OECD DAC donors, usually the volume of bilateral trade (Younas 2008), or the stock of foreign direct investment is used. These data however are not readily available in case of our four donors. We hope however that this will not weaken the explanatory power of our model, since the trade and economic interests of the Visegrád donors would mainly predict larger aid flows to the Balkans and the CIS regions, thus these interests may be captured sufficiently by the dummy variables relating to these two regions.

Depending on model specification, we have 201 to 207 data points in case of the pooled OLS estimation, and 723 data points for the fixed effects estimation. The number of data points basically represents the entire population, although we do have a few missing observations in case of which data on income levels and economic growth is not available. These are Cuba, North-Korea, the Palestinian Administration (PA) and Somalia. Except for the PA, neither of these countries receives large amounts of aid from the V4 countries, so we do think that dropping these observations will bias the results. The number of data points should be enough for a meaningful regression analysis, as most regression textbooks agree that there should be at least ten times as many observations as variables, a condition that is more than met in our case.

\subsection{Estimation results and robustness checks}

Table 2 contains the results of the estimation of our model outlined above, as well as some simple sensitivity tests. In model (1) we use the pooled OLS method. The conclusions from this first model are quite straightforward: the four Visegrád countries do not take into account the level of poverty or the performance of their recipients when determining their aid allocation, as neither GDP per capita (gdp_cap, included in logarithm form), neither the level of GDP growth (gdp_gr), nor the quality of institutions (measured with the index from Freedom House, variable FH) are statistically significant. It seems that these emerging donors make their aid allocation decisions based exclusively on the population level of the recipient (pop, also included in logarithm form), geographic proximity (variables Balkan and CIS), former relations (pre1989), and international obligations in case of Afghanistan and Iraq (Afg_Iraq), as all these variables are statistically significant. A further interesting observation is that the dummy variable relating to the second period (2005-2008, variable period2) is also 
marginally significant, which can imply that there has been a general scaling up of bilateral V4 aid to all recipients after the EU accession of these donors.

\section{[INSERT TABLE 2 HERE]}

The explanatory power of model (1) is reasonably high for such regressions (the size of the coefficient of determination $\left(\mathrm{R}^{2}\right)$ is 0.52$)$, therefore we can assume that our model has sufficient explanatory power. The results of estimating the first model therefore support all the hypotheses outlined in section 4.1., as well as the main arguments of our paper.

In model (2) of Table 2 we used the 'rule of law' index published by the World Bank to measure institutional quality, instead of Freedom House's index. This measure of institutional quality is also not significant, and adding it to the model does not really change anything. In model (3) we add a dummy for African countries, but it is also not significant, showing that the V4 donors do not give more aid to the African countries that would be most in need of it. Once again, adding this dummy does not change our previous results. Model (4) only contains the significant variables. By dropping the insignificant variables, the number of observations has been increased, and thus the overall explanatory power of the model also increases slightly. According to model (4) in Table 2, countries in the Western Balkans (Serbia, Bosnia and Herzegovina, Albania, Macedonia) ceteris paribus receive almost five times (393 percent) more aid from the Visegrád donors than any other of their partners. The CIS countries (and Georgia), as well as the pre-1989 partners also receive more aid, in both their cases the amounts are approximately 270 percent higher. Iraq and Afghanistan receive 469 percent more aid than other recipients with comparable characteristics.

In model (5) we try a different method to check the robustness of our estimations above. Instead of using two four year period averages of the aid recipient countries, we include all recipients on a country-year basis, greatly increasing the number of observations. We estimate this panel with a fixed effects method, with which we can account for unobserved recipient heterogeneity. This different method gives us similar results as the pooled-OLS method does. Although coefficients of the variables do change, the same variables turn out to be significant as in models (1) to (4). The $\mathrm{R}^{2}$ has greatly increased, but this is probably due to the larger number of observations, and should not make us to jump to any conclusions on which model is better. 
Our results therefore seem to be relatively robust: when determining the allocation of their bilateral aid, the Visegrád donors do not take into consideration the income levels of the recipients, their economic performance, nor the quality of their political or economic institutions. Besides the size of the population in the recipient countries, the only significant explanatory factors are related to geographic proximity, pre-1989 relations and in case of Afghanistan and Iraq the existence of international commitments. All models examined have an $\mathrm{R}^{2}$ between 0.52 and 0.76 , which can be regarded as reasonably high in case of such regressions. Of course, it is not possible to obtain too high explanatory power, as the foreign aid allocation of a donor country is always affected by unforeseen events (such as natural catastrophes which require urgent humanitarian assistance) or ad hoc political considerations, which would be difficult to model.

So far we have assumed that all four Visegrád countries behave in a similar manner when determining their aid allocation. Our analysis above has confirmed that there are broad similarities. However, bundling together the aid given by these four countries may mask some important individual characteristics. Therefore, we also estimate regression (1) from Table 2 using individual aid allocation data. The results of these estimates are shown in Table 3.

\section{[INSERT TABLE 3 HERE]}

While the individual country estimates in Table 3 do confirm the broad trends discussed earlier, they also point to some interesting individual characteristics. In contrary to the general trends we observed, it seems that the Czech Republic for example does prefer to give more aid to countries that are more democratic. This is result not only statistically significant, but also economically meaningful: a country which improves its Freedom House score by one point gets 15 percent more aid from the Czech Republic. We can also observe a similar behavior in case of Poland. Hungary also seems to be an interesting case, as the recipient country's level of population is not statistically significant. This would imply that Hungary does not give more aid to recipients with larger population levels, a result that is quite surprising and unusual. Slovakia however seems to be the country which differs most from the other three. The per capita income levels of the recipients are significant - although only marginally - which means that the country may actually have a poverty focus, in contrast with the other three. Also, being a former Soviet country or a pre-1989 partner does not explain the amount of aid a country gets from Slovakia. However, the $\mathrm{R}^{2}$ of these individual models is the lowest in case of Slovakia, which may imply that some important determining factors of aid 
allocation may be missing from our model. We must also note that the number of data points in the case of Hungary and Slovakia are relatively low (78 and 79), as they seem to have fewer partner countries than the Czech Republic and Poland. This may question the validity of these two regressions. In order to address this problem, we decreased the number of variables by dropping the insignificant ones and reran the regression. The results did not change. These individual country characteristics would definitely warrant further study.

\subsection{Limitations}

Our analysis has confirmed that there are broad similarities among the aid allocation decisions of the V4 emerging donors, which may differ than those observable in case of the OECD DAC members. We have also shown some individual country characteristics as well. However, our approach does have some limitations, and while our results do confirm earlier, mainly cased study based evidence (such as Drozd 2007; Bucar and Mrak 2007; Kiss 2007), we must examine how these limitations may distort our results. One of the main sources of such limitations is the structure of bilateral aid provided by the V4 countries, and how this structure is not reflected in the data on aid provided by the OECD. As mentioned earlier, a large portion of V4 aid never leaves the donor country. According to the OECD's methodology for calculating ODA, debt forgiveness, refugee costs, and scholarships to students from developing countries are also considered as foreign aid. Using the data provided by the OECD, it is not possible to purge bilateral aid data from these "inflating" factors. According to estimates of CONCORD (2009: 39), the European NGO Confederation for Relief and Development, such inflated items made up 14\% of the total aid provided by the Czech Republic in 2008. Estimates are not available for the other three countries. Still, it is possible to at least speculate on what kind of bias these problems with aid data add to our regression results, although a thorough analysis is definitely out of the scope of our paper.

It is quite clear that the debt forgiveness and refugee costs are not driven by the same motivations as true bilateral aid, and the motivations behind allocating scholarships may also differ. Forgiven debt included as ODA is likely to introduce an upward bias for the coefficients of the pre-1989 partner countries, as well as that of Iraq and Afghanistan. This is mainly due to the fact that the debts forgiven in past decade by the V4 countries were, in most cases related to concessional and commercial loans (export credits) provided to developing countries, mainly to ones which oriented themselves towards the Eastern block (Stojanos 2006). In the past years Poland gave large scale debt relief to Angola, Slovakia to 
Afghanistan, Hungary to Ethiopia and Iraq (Manning 2007: 100-102; CONCORD 2009). Some countries which were granted debt relief, such as Nicaragua in the case of the Czech Republic or Sudan in case of Slovakia were not considered as pre-1989 partner countries. As both of them are very poor countries, debt relief to them should bias the coefficient of GDP per capita downwards, which is not significant even with this bias.

The bias coming from refugee costs may be more difficult to determine. Although we do not have any data on how much refugee costs the V4 donors include in their ODA statistics, we do have data on the number and countries of origin of persons applying for asylum in these countries, which can be a reasonable proxy, although far from perfect. Table 4 shows the countries of origin for persons applying for asylum status in the four countries between 2001 and 2008. Among the top source countries we can see both countries belonging to the CIS region (Russia, Ukraine, Belarus), the Western Balkans and pre-1989 partners (Mongolia, Vietnam), as well as other developing countries such as Somalia, Bangladesh, Pakistan or Nigeria. Afghanistan and Iraq also figure prominently. Due to this heterogeneity, it is likely that the costs of refugees may put a bias in all our coefficients, but the exact size of it cannot be determined.

\section{[INSERT TABLE 4 HERE]}

Scholarships to developing country students perhaps distort our results the least, as in case of the V4 countries they are not significant amounts. In case of the Czech Republic, student costs made up $5.6 \%$ of bilateral aid in 2008 , and once again we have no data on the other countries (OECD 2010). Also, we do not know much on the regional composition of the incoming students, so speculating on the bias these costs may introduce would definitely require further research and data collection.

Problems with the data on aid can therefore impose some limitations on our results. We are also aware of the fact that our regression analysis would require further tests and perhaps methods more sophisticated than OLS or fixed effects estimation in order to be truly robust. However, as our conclusions are in line with the stylized facts and the limited case study evidence, we feel our model identifies well the factors that influence aid allocation in the four emerging donors, and the biases from data problems do not invalidate our results.

\section{Conclusions}


In our paper we analyzed the foreign aid policies of the four emerging Visegrád donors with a special emphasis on the factors that determine the allocation of their aid resources. The conclusions that can be drawn from our analysis clearly support the main hypothesis of our paper: the level of poverty (measured by per capita GDP) and the previous performance of the recipients (measured by the rate of economic growth or the quality of institutions) are not significant factors in explaining the aid allocation decisions of the four donor countries.

According to our results, the Visegrád donors seem to behave in a similar fashion to the donors that the literature has labeled 'egoistic', at least when it comes to their aid allocation. The four countries mainly support recipients in relation to which they have political, security and economic interests, as countries in the Western Balkans and the CIS region are the most important recipients. The reduction of global poverty is clearly not a consideration. While this observed aid allocation is in line with the political and economic interests of the four donor countries, the question arises how much it is due to strategic decisions. It is plausible for example that the Visegrád countries only choose recipients from their 'neighborhood' for reasons of convenience. Providing large scale foreign aid to extremely poor countries in SubSaharan Africa or other far away developing regions would be much more costly, and the experience of the four emerging donors in those areas is also much less. A further explanation may be that the four donors have some kind of perceived or actual comparative advantage compared to other donors in the Western Balkan and CIS regions. Therefore, more than one explanation may be possible for the observed 'egoistic' aid allocation, but determining which one is relevant is beyond the scope of this current paper.

Besides confirming these general trends, our paper has also contributed to the literature by identifying some donor specific characteristics. The Czech Republic and Poland do seem to put some emphasis on selecting countries that are more democratic. Hungary does not seem to take the size of the recipients into consideration, as larger countries do not get more aid from it. Slovakia seems to have the clearest break with its Communist past, as countries that were partners of Czechoslovakia before 1989 do nor receive more aid from Slovakia today. Analyzing these individual country characteristics, as well as their reasons and consequences is an interesting area of future case study-based research.

\section{References}


Alesina, Alberto and David Dollar (2000) 'Who Gives Foreign Aid to Whom and Why?', Journal of Economic Growth 5(1): 33-63.

Alesina, Alberto and Beatrice Weder (2002) 'Do Corrupt Governments Receive Less Foreign Aid?', American Economic Review 92(4): 1126-37.

Baginski, Pavel (2002): 'Poland', In: Michael Dauderstädt, ed. EU Eastern enlargement and development cooperation, Bonn: Friedrich-Ebert-Stiftung.

Bandyopadhyay, Subhayu and Howard J. Wall (2006) 'The Determinants of Aid in the PostCold War Era', Federal Reserve Bank of St. Louis Working Paper 2006-021B.

Berthélemy, Jean-Claude (2006) 'Bilateral Donors' Interest vs. Recipients' Development Motives in Aid Allocation: Do All Donors Behave the Same?', Review of Development Economics 10(2): 179-194.

Brainad, Lael et al. (2003) The Other War. Global Poverty and the Millenium Challenge Account, Washington D.C.: Brookings Institute Press.

Bucar, Maja and Mojmir Mrak (2007) 'Challenges of development cooperation for EU New member states', presented at the ABCDE World Bank Conference, Bled, Slovenia, May 17-18, 2007.

Burnell, Peter (2005) 'Foreign Aid Resurgent: New Spirit or Old Hangover?', in Tony Addison and George Mavrotas, eds. Building the New International Financial Architecture: Issues, Challenges and Agendas. London and Helsinki: PalgraveMacmillan/UNU-WIDER

Carbone, Maurizio (2004) 'Development Policy', in Neill Nugent, ed. EU Enlargement, Basingstoke: Palgrave.

Collier, Paul and David Dollar (2002) 'Aid Allocation and Poverty Reduction', European Economic Review 46(3): 1475-1500.

Collier, Paul et al. (2003) Breaking the Conflict Trap. Civil War and DevelopmentPolicy. Washington, DC: World Bank and Oxford University Press.

CONCORD (2009) Lighten the load. In a time of crisis, European aid has never been more important. Brussels: CONCORD

Danielson, Anders and Lennart Wohlgemuth (2005) 'Swedish Development Co-operation in Perspective', in Paul Hoebink and Olav Stokke, eds. Perspectives on European Development Cooperation, London: Routledge.

Development Co-operation Poland (2007) Annual Report 2006, Warsaw: Ministry of Foreign Affairs.

Dollar, David and Victoria Levin (2004) 'The Increasing Selectivity of Foreign Aid, 19842002', World Bank Policy Research Paper 3299.

Drozd, Maciej (2007) The New Face of Solidarity: A Brief Survey of Polish Aid, Manuscript. http://papers.ssrn.com/sol3/Delivery.cfm/SSRN ID1132246 code948600.pdf?abstractid $=1132246 \&$ mirid $=2,(21$ May 2009).

Eurobarometer (2007) 'Europeans and Development Aid', Special Eurobarometer 280. http://ec.europa.eu/public opinion/archives/ebs/ebs 280 en.pdf, (1 April 2009).

European Consensus (2005): Joint Statement by the Council and the representatives of the Governments of the Member States meeting within the Council, the European Parliament and the Commission on European Union Development Policy: 'The European Consensus'. 
European Council (2002) Presidency Conclusions. Barcelona European Council, 15 and 16 May 2002.

http://www.consilium.europa.eu/ueDocs/cms Data/docs/pressData/en/ec/71025.pdf (5 June 2010)

Gounder, Rukmani (1994) 'Empirical results of aid motivations: Australia's bilateral aid program', World Development 22(1): 99-113.

Harmer, Adele and Lin Cotterrell (2005) 'Diversity in donorship: the changing landscape of official humanitarian aid: Aid donorship in Central Europe', HPG Research Report 20, London: Overseas Development Institute.

Hoebink, Paul and Olav Stokke, eds. (2005) Perspectives on European Development Cooperation. London: Routledge.

HUN-IDA (2004) A magyar müszaki-tudományos együttmüködés és segitségnyújtás négy évtizedének rövid áttekintése napjainkig [A short history of the four decades of Hungarian technical and scientific cooperation and assistance], Manuscript. Budapest: HUN-IDA Kht.

Isopi, Alessia and George Mavrotas (2006) 'Aid Allocation and Aid Effectiveness. An Empirical Analysis', UNU-WIDER Research Paper No. 2006/07.

Kiss, Judit (2007) A magyar nemzetközi fejlesztéspolitika a számok tükrében [Hungary’s international development policy in numbers], Budapest: HAND Aid Watch Working Group.

Lightfoot, Simon (2008) 'Enlargement and the challenge of EU development policy', Perspectives on European Politics and Society 9(2): 128-142.

Lightfoot, Simon (2010) 'The Europeanisation of International Development Policies: The Case of Central and Eastern European States', Europe-Asia Studies 62(2): 329 - 350.

Lister, Marjorie and Maurizio Carbone, eds. (2006) New pathways in international development: gender and civil society in EU policy. Aldershot: Ashgate

Maizels, Alfred and Machiko K. Nissanke (1984) 'Motivations for Aid to Developing Countries', World Development 12(9): 879-900.

Manning, Richard (2007) Development Co-operation Report 2007. Paris: OECD

McGillivray, Mark (2003) 'Modeling Aid Allocation. Issues, approaches and results', UNUWIDER Research Paper 2003/49.

McGillivray, Mark et al (2005) 'It Works; It Doesn't; It Can, But That Depends... 50 Years of Controversy over the Macroeconomic Impact of Development Aid', UNU-WIDER Research Paper 2005/54.

McKinley, Robert D. and Richard Little (1979) 'The U.S. aid relationship: a test of the recipient need and the donor interest models', Political Studies 27(2): 236-250.

Michaux, Valérie (2002) 'EU enlargement. A brake of development cooperation?', The ACPEU Courier No. 193, July-August.

Morgenthau, Hans (1962) 'A Political Theory of Foreign Aid', The American Political Science Review 56(2): 301-309.

Neumayer, Eric (2003) 'Do Human Rights Matter in Bilateral Aid Allocation? A Quantitative Analysis of 21 Donor Countries', Social Science Quarterly 84(3): 650-666.

OECD (2007a) Development Co-operation Report Statistical Annex, Paris: OECD. 
OECD (2007b) Development Cooperation of the Czech Republic. DAC Special Review, Paris: OECD.

OECD (2008) Development Co-operation Report Statistical Annex, Paris: OECD.

OECD (2009) Development Co-operation Report Statistical Annex, Paris: OECD.

Radelet, Steven (2003) 'Bush and Foreign Aid', Foreign Affairs 85(5): 104-117.

Roodman, David (2007) 'Macro Aid Effectiveness: A Guide for the Perplexed', Center for Global Development Working Paper No. 134.

Rotberg, Robert I. (2002) 'The New Nature of Nation-State Failure', The Washington Quarterly 25(3): 85-96.

Schraeder, Peter J., Steven W. Hook and Bruce Taylor (1998) 'Clarifying the Foreign Aid Puzzle: A Comparison of American, Japanese, French, and Swedish Aid Flows', World Politics 50(2): 294-323.

SlovakAid (2006) National Programme of the Official Development Assistance, Bratislava: SlovakAid.

Stojanos, Robert (2006) Official Development Assistance and Debt Relief in Central EuropeCase Study of the Czech Republic.

http://projects.osu.eu/igeography/docs/ODA_and_Debt_Relief_case_study_CR.pdf (6 April 2010).

Szentes, Tamás (s. a.) Aid and Trade Relations between the South and the East European Countries, Manuscript.

Szent-Iványi, Balázs and András Tétényi (2008) 'Transition and foreign aid policies in the Visegrád countries. A path dependant approach', Transition Studies Review 15(3): 573 587.

Szent-Iványi, Balázs (2007) 'State Fragility and International Development Co-operation', UNU-WIDER Research Paper No. 2007/29.

Trumbull, William N. and Howard J. Wall (1994) 'Estimating Aid-Allocation Criteria with Panel Data', The Economic Journal 104(425): 876-882.

UNHCR (2010) UNHCR Statistical Online Population Database http://apps.who.int/globalatlas/dataQuery/default.asp

Weissman, Stephen R. (1997): 'Addicted to Mobutu: why America can’t learn from its foreign policy mistakes', Washington Monthly, 1997 September

World Bank (2007) The Czech ODA program in the current aid paradigm: challenges and opportunities for a more efficient aid. Presentation for the Ministry of Finance, February 22, 2007, Prague. http://www.mfcr.cz/cps/rde/xbcr/mfcr/Czech_ODA_program challenges and opportunities.ppt (30 September 2008).

World Bank (2009a) World Development Report 2010: Development and Climate Change. Washington D.C.: World Bank

World Bank (2009b) Governance Matters 2009 Brochure. http://info.worldbank.org/governance/wgi/pdf/WBI GovInd.pdf

Younas, Javed (2008) 'Motivation for bilateral aid allocation: Altruism or trade benefits', European Journal of Political Economy 24(3): 661-674.

Zagranica Group (2007) Polish Development Assistance. Independent research conducted by non-governmental organizations, Warsaw: Zagranica Group 
http://www.zagranica.org.pl/index.php?option $=$ com docman\&task $=$ doc view\&gid $=37$ \&Itemid=138 (21 May 2009). 


\section{Tables}

Table 1. ODA/GNI ratios in the Visegrád countries between 2002 and 2008, in percent

\begin{tabular}{lrrrrrrr}
\hline & $\mathbf{2 0 0 2}$ & $\mathbf{2 0 0 3}$ & $\mathbf{2 0 0 4}$ & $\mathbf{2 0 0 5}$ & $\mathbf{2 0 0 6}$ & $\mathbf{2 0 0 7}$ & $\mathbf{2 0 0 8}$ \\
\hline Czech Republic & 0,07 & 0,10 & 0,11 & 0,11 & 0,12 & 0,11 & 0,12 \\
Hungary &.. & 0,03 & 0,06 & 0,11 & 0,13 & 0,08 & 0,08 \\
Poland &.. & 0,01 & 0,05 & 0,07 & 0,09 & 0,09 & 0,08 \\
Slovakia & 0,02 & 0,05 & 0,07 & 0,12 & 0,10 & 0,09 & 0,10 \\
$\begin{array}{l}\text { OECD DAC } \\
\text { average }\end{array}$ & 0,23 & 0,25 & 0,26 & 0,33 & 0,31 & 0,28 & 0,31 \\
\hline
\end{tabular}

Source: OECD 2007a: 33; 2008: 33.; 2009: 33. 
Table 2. Estimates for the aid allocation of the Visegrád donors between 2001 and 2008

\begin{tabular}{|c|c|c|c|c|c|}
\hline \multicolumn{6}{|c|}{ Dependent variable: $\log (\mathrm{V} 4 \mathrm{ODA})$} \\
\hline & $\begin{array}{c}\text { (1) } \\
\text { Pooled OLS }\end{array}$ & $\begin{array}{c}(2) \\
\text { Pooled OLS }\end{array}$ & $\begin{array}{c}\text { (3) } \\
\text { Pooled OLS }\end{array}$ & $\begin{array}{c}(4) \\
\text { Pooled OLS }\end{array}$ & $\begin{array}{c}\text { (5) } \\
\text { Fixed effects }\end{array}$ \\
\hline $\log ($ gdp_cap $)$ & $\begin{array}{c}0.093 \\
(0.742)\end{array}$ & $\begin{array}{c}0.105 \\
(0.775)\end{array}$ & $\begin{array}{c}0.032 \\
(0.175)\end{array}$ & - & $\begin{array}{l}0.202 \\
(0.888)\end{array}$ \\
\hline $\log ($ pop $)$ & $\begin{array}{c}0.605^{*} \\
{[0.448 ; 0.763]} \\
(10.001)\end{array}$ & $\begin{array}{c}0.603 * \\
{[0.440 ; 0.765]} \\
(9.65)\end{array}$ & $\begin{array}{c}0.594^{*} \\
{[0.423 ; 0.765]} \\
(9.055)\end{array}$ & $\begin{array}{c}0.599 * \\
{[0.443 ; 0.755]} \\
(9.964)\end{array}$ & $\begin{array}{c}0.319^{*} \\
{[0.037 ; 0.603]} \\
(2.915)\end{array}$ \\
\hline gdp_gr & $\begin{array}{c}-0.002 \\
(-0.086)\end{array}$ & $\begin{array}{c}-0.002 \\
(-0.085)\end{array}$ & $\begin{array}{l}0.0002 \\
(0.006)\end{array}$ & - & $\begin{array}{c}0.006 \\
(0.425)\end{array}$ \\
\hline FH & $\begin{array}{l}-0.0001 \\
(-0.002)\end{array}$ & - & $\begin{array}{c}-0.005 \\
(-0.065)\end{array}$ & - & $\begin{array}{c}-0.037 \\
(-0.435)\end{array}$ \\
\hline RoL & - & $\begin{array}{c}-0.04 \\
(-0.185)\end{array}$ & - & - & - \\
\hline Balkan & $\begin{array}{c}3.848^{*} \\
{[2.724 ; 4.972]} \\
(8.91)\end{array}$ & $\begin{array}{c}3.833^{*} \\
{[2.688 ; 4.978]} \\
(8.71)\end{array}$ & $\begin{array}{c}3.809^{*} \\
{[2.667 ; 4.952]} \\
(8.676)\end{array}$ & $\begin{array}{c}3.932 * \\
{[2.856 ; 5.008]} \\
(9.503)\end{array}$ & $\begin{array}{c}2.456^{*} \\
{[1.195 ; 3.722]} \\
(5.028)\end{array}$ \\
\hline CIS & $\begin{array}{c}2.662 * \\
{[1.733 ; 3.592]} \\
(7.455)\end{array}$ & $\begin{array}{c}2.642^{*} \\
{[1.690 ; 3.595]} \\
(7.219)\end{array}$ & $\begin{array}{c}2.579^{*} \\
{[1.578 ; 3.580]} \\
(6.703)\end{array}$ & $\begin{array}{c}2.656^{*} \\
{[1.762 ; 3.550]} \\
(7.727)\end{array}$ & $\begin{array}{c}2.419^{*} \\
{[1.080 ; 3.762]} \\
(4.664)\end{array}$ \\
\hline pre1989 & $\begin{array}{c}2.526^{*} \\
{[1.406 ; 3.646]} \\
(5.868)\end{array}$ & $\begin{array}{c}2.519^{*} \\
{[1.416 ; 3.629]} \\
(5.940)\end{array}$ & $\begin{array}{c}2.473^{*} \\
{[1.312 ; 3.635]} \\
(5.541)\end{array}$ & $\begin{array}{c}2.455^{*} \\
{[1.387 ; 3.525]} \\
(5.974)\end{array}$ & $\begin{array}{c}1.235^{*} \\
{[0.163 ; 2.307]} \\
(2.977)\end{array}$ \\
\hline Afg_Iraq & $\begin{array}{c}4.809 * \\
{[4.059 ; 5.558]} \\
(16.689)\end{array}$ & $\begin{array}{c}4.768^{*} \\
{[3.783 ; 5.753]} \\
(12.592)\end{array}$ & $\begin{array}{c}4.637^{*} \\
{[3.520 ; 5.755]} \\
(10.797)\end{array}$ & $\begin{array}{c}4.689^{*} \\
{[4.023 ; 5.355]} \\
(18.313)\end{array}$ & $\begin{array}{c}3.440 * \\
{[2.321 ; 4.568]} \\
(7.907)\end{array}$ \\
\hline period 2 & $\begin{array}{c}0.432 * * * \\
{[0.063 ; 0.800]} \\
(1.936)\end{array}$ & $\begin{array}{c}0.423 * * * \\
{[0.062 ; 0.795]} \\
(1.935)\end{array}$ & $\begin{array}{c}0.437^{*} \\
{[0.068 ; 0.805]} \\
(0.052)\end{array}$ & $\begin{array}{c}0.437 * * \\
{[0.036 ; 0.839]} \\
(2.147)\end{array}$ & - \\
\hline Africa & - & - & $\begin{array}{c}-0.186 \\
(-0.535)\end{array}$ & - & - \\
\hline constant & $\begin{array}{c}-4.767 * \\
{[-7.636 ;-1.705]} \\
(-4.097)\end{array}$ & $\begin{array}{c}-4.776^{*} \\
{[-7.727 ;-1.824]} \\
(-4.210)\end{array}$ & $\begin{array}{c}-4.070^{* *} \\
{[-7.517 ;-0.623]} \\
(-2.329)\end{array}$ & $\begin{array}{c}-3.930 * \\
{[-4.504 ;-3.355]} \\
(-17.792)\end{array}$ & - \\
\hline $\mathrm{R}^{2}$ & 0.52 & 0.52 & 0.52 & 0.55 & 0.76 \\
\hline Adj. $\mathrm{R}^{2}$ & 0.50 & 0.50 & 0.50 & 0.53 & 0.71 \\
\hline $\begin{array}{l}\text { Number of } \\
\text { observations (n) }\end{array}$ & 201 & 201 & 201 & 207 & 723 \\
\hline
\end{tabular}

Notes: t-statistics in parenthesis. The standard errors are heteroskedasticity-robust (using White's method). Model (5) also contains year dummies which are jointly significant at the $1 \%$ level. Confidence intervals are included in square brackets at the appropriate significance level for significant coefficients.

$*=$ Significant at the 1 percent level.

$* *=$ Significant at the 5 percent level.

$* * *=$ Significant at the 10 percent level. 
Table 3. Pooled OLS estimates for the aid allocation of individual Visegrád donors between 2001 and 2008

\begin{tabular}{|c|c|c|c|c|}
\hline \multicolumn{5}{|c|}{ Dependent variable: $\log$ of ODA provided by individual donors } \\
\hline & $\begin{array}{c}\text { (1) } \\
\text { Czech Republic }\end{array}$ & $\begin{array}{c}\text { (2) } \\
\text { Hungary }\end{array}$ & $\begin{array}{c}\text { (3) } \\
\text { Poland }\end{array}$ & $\begin{array}{c}\text { (4) } \\
\text { Slovakia }\end{array}$ \\
\hline $\log ($ gdp_cap $)$ & $\begin{array}{c}0.088 \\
(0.844)\end{array}$ & $\begin{array}{c}-0.123 \\
(-0.329)\end{array}$ & $\begin{array}{c}0.129 \\
(1.213)\end{array}$ & $\begin{array}{c}-0.519 * * * \\
{[-0.955 ;-0.083]} \\
(2.248)\end{array}$ \\
\hline $\log (\mathrm{pop})$ & $\begin{array}{c}0.409^{*} \\
{[0.247 ; 0.571]} \\
(6.565)\end{array}$ & $\begin{array}{c}0.189 \\
(1.408)\end{array}$ & $\begin{array}{c}0.426^{*} \\
{[0.206 ; 0.646]} \\
(5.052)\end{array}$ & $\begin{array}{c}0.185 \\
(1.400)\end{array}$ \\
\hline gdp_gr & $\begin{array}{c}-0.018 \\
(-0.838)\end{array}$ & $\begin{array}{c}0.003 \\
(0.036)\end{array}$ & $\begin{array}{c}-0.015 \\
(-0.509)\end{array}$ & $\begin{array}{c}0.278 \\
(0.436)\end{array}$ \\
\hline FH & $\begin{array}{c}-0.15^{* *} \\
{[-0.307 ;-0.005]} \\
(-2.045)\end{array}$ & $\begin{array}{c}-0.067 \\
(-0.537)\end{array}$ & $\begin{array}{c}0.166^{* *} \\
{[0.006 ; 0.325]} \\
(2.048)\end{array}$ & $\begin{array}{c}-0.039 \\
(-0.314)\end{array}$ \\
\hline Balkan & $\begin{array}{c}2.683^{*} \\
{[1.632 ; 3.733]} \\
(6.647)\end{array}$ & $\begin{array}{c}3.331^{*} \\
{[1.532 ; 5.129]} \\
(4.908)\end{array}$ & $\begin{array}{c}2.838^{*} \\
{[1.170 ; 4.507]} \\
(4.439)\end{array}$ & $\begin{array}{c}1.987^{*} \\
{[0.504 ; 3.471]} \\
(3.549)\end{array}$ \\
\hline CIS & $\begin{array}{c}1.785^{*} \\
{[0.899 ; 2.672]} \\
(5.246)\end{array}$ & $\begin{array}{c}1.723^{*} \\
{[0.090 ; 3.370]} \\
(2.795)\end{array}$ & $\begin{array}{c}2.431^{*} \\
{[1.358 ; 3.503]} \\
(5.916)\end{array}$ & $\begin{array}{c}0.660 \\
(1.327)\end{array}$ \\
\hline pre1989 & $\begin{array}{c}1.577^{*} \\
{[0.398 ; 2.756]} \\
(3.482)\end{array}$ & $\begin{array}{c}2.366^{*} \\
{[0.152 ; 4.580]} \\
(2.833)\end{array}$ & $\begin{array}{c}1.621^{*} \\
{[0.031 ; 3.212]} \\
(2.661)\end{array}$ & $\begin{array}{c}-0.255 \\
(-0.410)\end{array}$ \\
\hline Afg_Iraq & $\begin{array}{c}5.097^{*} \\
{[4.564 ; 5.630]} \\
(24.913)\end{array}$ & $\begin{array}{c}4.715^{*} \\
{[1.988 ; 7.442]} \\
(4.582)\end{array}$ & $\begin{array}{c}2.893 * \\
{[2.238 ; 3.548]} \\
(11.528)\end{array}$ & $\begin{array}{c}1.728^{* *} \\
{[0.110 ; 3 ; 346]} \\
(2.131)\end{array}$ \\
\hline period2 & $\begin{array}{c}0.149 \\
(0.721)\end{array}$ & $\begin{array}{c}-0.320 \\
(-0.767)\end{array}$ & $\begin{array}{c}0.654 * \\
{[0.017 ; 1.291]} \\
(2.681)\end{array}$ & $\begin{array}{c}0.959 * * \\
{[0.108 ; 1.809]} \\
(2.248)\end{array}$ \\
\hline constant & $\begin{array}{c}-3.439^{*} \\
{[-5.910 ;-0.969]} \\
(-3.625)\end{array}$ & $\begin{array}{c}-2.729 \\
(-0.756)\end{array}$ & $\begin{array}{c}-6.227^{*} \\
{[-9.021 ;-3.434]} \\
(-5.820)\end{array}$ & $\begin{array}{c}0.977 \\
(0.402)\end{array}$ \\
\hline $\mathrm{R}^{2}$ & 0.37 & 0.42 & 0.38 & 0.32 \\
\hline Adj. $R^{2}$ & 0.34 & 0.34 & 0.34 & 0.23 \\
\hline $\begin{array}{l}\text { Number of } \\
\text { observations (n) }\end{array}$ & 188 & 78 & 154 & 79 \\
\hline
\end{tabular}

Notes: t-statistics in parenthesis. The standard errors are heteroskedasticity-robust (using White's method). Confidence intervals are included in square brackets at the appropriate significance level for significant coefficients.

$*=$ Significant at the 1 percent level.

$* *=$ Significant at the 5 percent level.

$* * *=$ Significant at the 10 percent level. 
Table 4. Number of people seeking asylum status in the Visegrád countries by country of origin, 2001-2008

\begin{tabular}{|l|r|l|r|}
\hline Russia & 58422 & Serbia & 4071 \\
\hline Afghanistan & 16506 & Pakistan & 4065 \\
\hline India & 12845 & Slovakia & 3292 \\
\hline Ukraine & 10583 & Romania & 2638 \\
\hline Iraq & 8287 & Belarus & 2504 \\
\hline China & 7640 & Turkey & 1897 \\
\hline Viet Nam & 7114 & Mongolia & 1639 \\
\hline Moldova & 7081 & Somalia & 1597 \\
\hline Georgia & 5453 & Nigeria & 1453 \\
\hline Bangladesh & 5358 & Iran & 1128 \\
\hline Armenia & 4163 & & \\
\hline
\end{tabular}

Only countries with more than 1000 applicants between 2001 and 2008 are listed 
Appendix: Data sources

\begin{tabular}{ll}
\hline \multicolumn{1}{c}{ Variable } & \multicolumn{1}{c}{ Data source } \\
\hline Per capita GDP (gdp_cap) & IMF World Economic Outlook Database \\
& Online \\
Population data (pop) & IMF World Economic Outlook Database \\
& Online \\
GDP growth rate (gdp_gr) & IMF World Economic Outlook Database \\
ODA data (V4ODA) & Online \\
Freedom House index (FH) & OECD StatExtracts Online \\
'Rule of Law' index (RoL) & Freedom House: Freedom in the World \\
& Online \\
\hline
\end{tabular}

